ACTA THERIOLOGICA

Vol. 31, 25: 327-342, 1986

BISONANIA XCI

\title{
Shape, Size and Weight of the Heart in European Bison
}

\author{
Mieczysław WĘGRZYN \& Marta KUPCZYŃSKA
}

\begin{abstract}
Węgrzyn M. \& Kupczyńska M., 1986: Shape, size and weight of the heart in European bison. Acta theriol., 31, 25: 327-342 [With 6 Tables \& 3 Figs.]

Examination was made of 117 hearts of European bison of both sexes and of different ages. The fresh hearts were weighed, then fixed in $5 \%$ formalin water solution and linear measurements carried out on them. Two morphological types of heart were observed to occur in European bison - the first being similar in shape to a broad, and the other to a narrow cone, while distinct differences were found in respect of several indices. The dimensions of the heart do not increase evenly, which leads to gradual change in its shape. The absolute weight of the heart still increases after adult age is attained, while the relative weight gradually decreases with age and in adult European bison is established within limits of approximately $0.5 \%$. In older individuals, particularly females, the relative weight of the heart again increases.

[Dept. of Animal and Human Anatomy, Agricultural and Teachers University, Zytnia 17, 08-110 Siedlce, and Dept. of Animal Anatomy, Warsaw Agricultural University, Nowoursynowska 166, 02-776 Warszawa, Poland
\end{abstract}

\section{INTRODUCTION}

Few research workers have as yet dealt with the morphology of the heart in European bison. Albrecht (1957) described several characters of this organ (also giving some linear dimensions and weight) on the basis of observations of one 2-year old animal of unstated sex. Węgrzyn (1968) dealt more comprehensively with the morphology of the heart, including the linear measurements of 18 hearts of these animals of varying age and somewhat scanty data on the weight of the heart of males, which could not therefore give a complete picture of the external structure of the heart. In recent years it has proved possible to collect a larger number of European bison hearts and examine the external morphology of the heart in greater detail. 


\section{MATERIAL AND METHODS}

A total of 117 hearts of European bison of varying ages were examined (varying in age from 4 days to 23 years) of both sexes (63 males' and 54 females) registered (45 animals) in the European Bison Pedigree Books (Żabiński, 1947-65; Żabiński \& Raczyński, 1965-74), or originating from a free-ranging herd (72 animals).

Weight was measured on fresh hearts after removing the pericardium and shortening the arteries to $5 \mathrm{~cm}$, and veins to $2 \mathrm{~cm}$. The hearts were next fixed in $5 \%$ formalin water solution ${ }^{1}$ and linear measurements made. For this purpose measurement points were selected on the heart (Fig. 1) and used to make 15 measurements (Table 1), taking as guides the studies by Schubert (1909) and Plemjannikov (1954b and 1954c). The circumference and length were measured with a metal surveying tape, and height and breadth using a sliding scale with

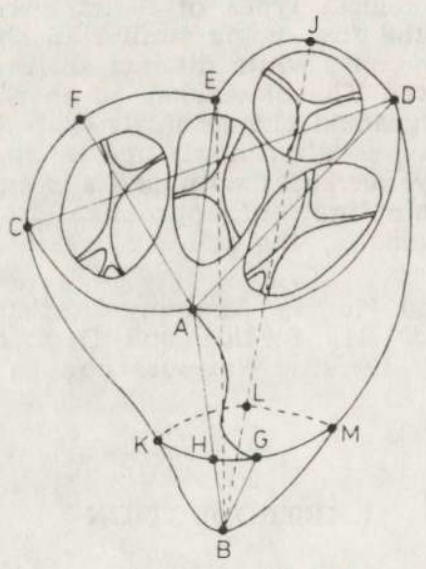

Fig. 1. Diagram of linear measurements of the heart (vertical part) in the European bison. Explanations given by linear measurements - Table 1.

a vernier $(0-10)$ or compasses. For the sake of comparison calculation was made of indices for the heart in cattle - on the basis of data contained in the paper by Schubert (1909) and for other Bovinae from the paper by Albrecht (1957), after which they were compared with the corresponding values obtained for European bison.

\section{RESULTS}

Two basic types of heart were distinguished for the European bison. Type I heart (Plate VIIIA), is characterized by relatively great width

${ }_{1}$ Some of the hearts (12) were fixed in whole carcasses by injections into the arteries (Pilarski et al. 1967). The majority of the dimensions of these hearts did not differ from the remainder. Only the data for circumference of the heart and of the right ventricle differed considerably in 5 cases. After applying the Q-Dixon test these data were omitted from the tables. 
of the base and fairly considerable lateral flattening (mean index 67.6). Its apex is massive, blunt ended and usually inclined backwards so that the left ventricle border becomes concave. The right ventricle is strongly developed and its conus arteriosus is situated high up. The base of the ventricles in this type of heart is decidedly transversely situated, its right ventricle border highest and the left ventricle border lowest in the vicinity of the atrial surface of the heart. The type of heart described above was observed chiefly in adult animals (in $58.3 \%$ of cases) and more often in males.

A slightly differently structured heart sometimes occurs in type I in adult European bison. The main difference is the position of the pulmonary trunk, which emerges in the centre of the auricular surface of the heart from the base of the ventricles (Plate VIII,B) and not as is usual, by the right ventricle border. The position of the two ventricles also differs in this case: the right (4) occupies a larger part of the auricular surface of the heart, while the left (5) is distinctly shifted on to its atrial surface. The sub-type of heart described occurs in $18.5 \%$ of European bison with type I heart, more often in females than in males.

Type II heart is shaped like a narrow and elongated cone (Plate VIII,C), more or less flattened laterally (mean index 76.2). Its right ventricle is more weakly developed and has a relatively lower conus arteriosus. The apex is less massive and either very slightly inclined backwards, or not at all, and consequently the left ventricle border is straight or slightly convex. The base of the ventricles in hearts of this type is only very slightly inclined forwards in relation to its axis. Type II heart occurred in the study material in $41.7 \%$ of cases, mainly in young animals and more often in females.

Absolute measurements show that the heart in European bison increases in size intensively up to the 5th year of life, that is, until physical maturity is reached (Empel, 1962; Empel \& Roskosz, 1963).

With increasing age the conus arteriosus rises and gradually the base of the ventricles inclines in relation to the long axis of the heart. This is confirmed by the differing increase of certain dimensions (Table 1): of height of the auricular surface of the heart (BE) and atrial surface (AB), height of conus arteriosus (BJ) and length of the right ventricle border (BMD) and left ventricle border (BKC), and also the circumference of the right ventricle (ADE).

The rate of growth of linear dimensions is not even (Table 2). The most rapid rate occurs in males in the age group from $1-3$ years, in addition to height of conus arteriosus and maximum width of the heart. Maximum growth rate in all the dimensions examined occurs in females 
Table 1

Average measurements of European bison heart (in $\mathrm{mm}$ ). Lower numbers denote standard deviations.

\begin{tabular}{|c|c|c|c|c|c|c|c|c|}
\hline Age group /In years/ & $0-6 / 12$ & $6 y 12-1$ & $1-3$ & $3-5$ & $5-7$ & $7-9$ & $10-17$ & $\mathrm{Cr}$ \\
\hline \multicolumn{9}{|c|}{ Males } \\
\hline$\frac{\text { Height: }}{\text { conus arteriogus /BJ/ }}$ & $\begin{array}{r}120.5 \\
14.5\end{array}$ & $\begin{array}{r}155.5 \\
11.1\end{array}$ & $\begin{array}{r}198.8 \\
11.0\end{array}$ & $\begin{array}{r}233.7 \\
9.8\end{array}$ & $\begin{array}{r}234.2 \\
16.4\end{array}$ & $\begin{array}{r}245.5 \\
7.5\end{array}$ & $\begin{array}{r}265.7 \\
6.7\end{array}$ & 3.0 \\
\hline auricular surface / RE/ & $\begin{array}{r}116.8 \\
12.6\end{array}$ & $\begin{array}{l}136.7 \\
10.3\end{array}$ & $\begin{array}{r}178.0 \\
9.4\end{array}$ & $\begin{aligned} 199.0 \\
11.2\end{aligned}$ & $\begin{array}{r}200.3 \\
4.5\end{array}$ & $\begin{array}{r}226.7 \\
5.7\end{array}$ & $\begin{array}{r}212.1 \\
16.3\end{array}$ & 8.3 \\
\hline atrial surface $\mid: B /$ & $\begin{array}{l}99.8 \\
13.3\end{array}$ & $\begin{aligned} 116.0 \\
10: 1\end{aligned}$ & $\begin{array}{r}143.3 \\
7.2\end{array}$ & $\begin{array}{r}160.4 \\
10.6\end{array}$ & $\begin{array}{r}165.3 \\
7.9\end{array}$ & $\begin{array}{r}185.0 \\
7.5\end{array}$ & 179.00 & 8.0 \\
\hline right ventricle / AH & $\begin{array}{r}82.8 \\
8.8\end{array}$ & $\begin{array}{r}95.6 \\
8.6\end{array}$ & $\begin{array}{r}116.1 \\
8.4\end{array}$ & $\begin{array}{r}131.6 \\
2.5\end{array}$ & $\begin{array}{r}135.8 \\
12.7\end{array}$ & $\begin{array}{r}155.7 \\
7.9\end{array}$ & $\begin{array}{r}150.0 \\
9.0\end{array}$ & 6.5 \\
\hline apex /BG/ & $\begin{array}{r}20.4 \\
5.9\end{array}$ & $\begin{array}{r}29.3 \\
4.2\end{array}$ & $\begin{array}{r}30.0 \\
4.9\end{array}$ & $\begin{array}{r}35.6 \\
2.6\end{array}$ & $\begin{aligned} 41.7 \\
7.7\end{aligned}$ & $\begin{aligned} 44.0 \\
7.9\end{aligned}$ & $\begin{array}{r}41.3 \\
6.3\end{array}$ & 16.5 \\
\hline \multicolumn{9}{|l|}{ Length: } \\
\hline left ventricle border / BKC/ & $\begin{array}{r}109.2 \\
15.7\end{array}$ & $\begin{array}{r}130.4 \\
10.8\end{array}$ & $\begin{array}{r}164.6 \\
15.3\end{array}$ & $\begin{array}{r}186.9 \\
17.1\end{array}$ & $\begin{array}{r}187.6 \\
17.9\end{array}$ & $\begin{array}{r}207.0 \\
16.9\end{array}$ & $\begin{array}{r}208.4 \\
16.1\end{array}$ & 10.4 \\
\hline right ventricle border / $30 D /$ & $\begin{array}{r}138.2 \\
16.2\end{array}$ & $\begin{array}{r}161.1 \\
19.7\end{array}$ & $\begin{array}{r}213.8 \\
16.1\end{array}$ & $\begin{array}{r}240.8 \\
26.0\end{array}$ & $\begin{array}{r}240.0 \\
20.9\end{array}$ & $\begin{array}{r}273.3 \\
8.5\end{array}$ & $\begin{array}{r}256.0 \\
28.5\end{array}$ & 12.0 \\
\hline$\frac{\text { Breadth: }}{\operatorname{maxinal} / \mathrm{CD} /}$ & $\begin{array}{l}94.0 \\
16.0\end{array}$ & $\begin{array}{r}123.0 \\
8.6\end{array}$ & $\begin{array}{r}155.7 \\
4.4\end{array}$ & $\begin{array}{r}194.4 \\
10.4\end{array}$ & $\begin{array}{r}186.2 \\
10.1\end{array}$ & $\begin{array}{r}210.7 \\
18.7\end{array}$ & $\begin{array}{r}209.0 \\
14.9\end{array}$ & 7.9 \\
\hline minimal /AE/ & $\begin{array}{r}67.0 \\
9.0\end{array}$ & $\begin{array}{r}84.6 \\
3.8\end{array}$ & $\begin{array}{r}112.0 \\
7.2\end{array}$ & $\begin{array}{r}139.2 \\
7.8\end{array}$ & $\begin{array}{r}127.0 \\
15.8\end{array}$ & $\begin{array}{r}154.3 \\
11.7\end{array}$ & $\begin{array}{r}134.0 \\
6.8\end{array}$ & 5.6 \\
\hline lest ventricle /AP/ & $\begin{array}{r}62.0 \\
8.0\end{array}$ & $\begin{array}{r}77.1 \\
5.5\end{array}$ & $\begin{array}{r}100.0 \\
6.3\end{array}$ & $\begin{array}{r}126.4 \\
8.8\end{array}$ & $\begin{array}{r}111.6 \\
5.2\end{array}$ & $\begin{array}{r}136.0 \\
13: 4\end{array}$ & 127.2 & 8.2 \\
\hline right ventricle / $A D /$ & $\begin{array}{r}79.0 \\
9.0\end{array}$ & $\begin{array}{r}99.2 \\
6.7\end{array}$ & $\begin{array}{r}126.0 \\
7.8\end{array}$ & $\begin{array}{r}149.8 \\
18.5\end{array}$ & $\begin{array}{r}134.2 \\
13.3\end{array}$ & $\begin{array}{r}174.0 \\
18.2\end{array}$ & $\begin{array}{r}157.8 \\
10.8\end{array}$ & 7.6 \\
\hline \multicolumn{9}{|l|}{ C1rcumference: } \\
\hline below the coronary groove /ADECA/ & $\begin{array}{r}302.0 \\
44.6\end{array}$ & $\begin{array}{r}341.7 \\
26.2\end{array}$ & $\begin{array}{r}435.8 \\
11.4\end{array}$ & $\begin{array}{r}520.6 \\
19.2\end{array}$ & 501.0 & $\begin{array}{r}587.6 \\
67.3\end{array}$ & $\begin{array}{r}577.0 \\
35.4\end{array}$ & 6.6 \\
\hline left ventricle /ACE/ & $\begin{array}{r}128.5 \\
16.0\end{array}$ & $\begin{array}{r}144.8 \\
10.1\end{array}$ & $\begin{array}{r}190.6 \\
13.5\end{array}$ & $\begin{aligned} 234.9 \\
13.2\end{aligned}$ & $\begin{array}{r}216.2 \\
25.7\end{array}$ & $\begin{array}{r}247.7 \\
23.5\end{array}$ & $\begin{array}{r}252.1 \\
15.0\end{array}$ & 6.1 \\
\hline right ventricle /ADE/ & $\begin{array}{r}173.3 \\
29.3\end{array}$ & $\begin{aligned} 196.8 \\
17.1\end{aligned}$ & $\begin{array}{r}256.6 \\
17.3\end{array}$ & $\begin{array}{r}290.2 \\
10.2\end{array}$ & $\begin{aligned} 294.0 \\
26.7\end{aligned}$ & $\begin{array}{l}340.0 \\
44.0\end{array}$ & $\begin{array}{r}324.9 \\
22.2\end{array}$ & 7.4 \\
\hline \multirow[t]{2}{*}{ apex /GMIXG/ } & $\begin{array}{r}105.5 \\
14.5\end{array}$ & $\begin{array}{r}135.0 \\
20.9\end{array}$ & $\begin{aligned} 169.7 \\
13.7\end{aligned}$ & $\begin{aligned} 216.2 \\
27.0\end{aligned}$ & $\begin{array}{r}213.2 \\
26.6\end{array}$ & $\begin{array}{r}226.5 \\
31.5\end{array}$ & $\begin{array}{r}225.0 \\
21.3\end{array}$ & 11.5 \\
\hline & $n=5$ & $n=7$ & $n=11$ & $n=7$ & $n=6$ & $n=3$ & $\mathrm{n}=7$ & \\
\hline \multicolumn{9}{|c|}{ Persales } \\
\hline conus arteriosus /BJ/ & 105.0 & $\begin{array}{r}149.7 \\
5.2\end{array}$ & $\begin{array}{r}171.7 \\
10.1\end{array}$ & $\begin{array}{r}200.4 \\
8.2\end{array}$ & $\begin{array}{r}216.5 \\
6.5\end{array}$ & & $\begin{array}{r}227.5 \\
9.0\end{array}$ & 4.2 \\
\hline auricular surface / BE/ & 83.0 & $\begin{aligned} 129.5 \\
4.3\end{aligned}$ & $\begin{array}{r}151.6 \\
8.6\end{array}$ & $\begin{array}{r}177.6 \\
5.7\end{array}$ & $\begin{array}{r}184.0 \\
0.0\end{array}$ & & $\begin{aligned} 196.0 \\
11.2\end{aligned}$ & 6.0 \\
\hline atrlal surface / $A B /$ & 73.0 & $\begin{aligned} 111.0 \\
2.1\end{aligned}$ & $\begin{array}{r}124.7 \\
10.0\end{array}$ & $\begin{array}{r}146.6 \\
1.9\end{array}$ & $\begin{aligned} 159.5 \\
2.5\end{aligned}$ & & $\begin{array}{l}159.1 \\
10.2\end{array}$ & 6.9 \\
\hline right ventricle / AH/ & 59.0 & $\begin{array}{r}93.2 \\
3.4\end{array}$ & $\begin{array}{r}101.9 \\
13.6\end{array}$ & $\begin{array}{r}114.4 \\
7.6\end{array}$ & $\begin{aligned} 133.5 \\
0.7\end{aligned}$ & & $\begin{array}{r}128.8 \\
8.6\end{array}$ & 6.9 \\
\hline apex /BG/ & 15.0 & $\begin{array}{r}25.5 \\
2.3\end{array}$ & $\begin{array}{r}28.9 \\
5.4\end{array}$ & $\begin{array}{r}39.2 \\
4.3\end{array}$ & $\begin{array}{r}34.5 \\
6.5\end{array}$ & & $\begin{array}{r}40.1 \\
5.7\end{array}$ & 14.8 \\
\hline \multicolumn{9}{|l|}{ Length: } \\
\hline left ventricle border / $\mathrm{BKC} /$ & 80.0 & $\begin{array}{r}121.7 \\
5.8\end{array}$ & $\begin{array}{r}141.0 \\
10.9\end{array}$ & $\begin{array}{r}170.4 \\
9.6\end{array}$ & $\begin{array}{r}185.0 \\
13.0\end{array}$ & & $\begin{array}{r}182.8 \\
19.3\end{array}$ & 11.0 \\
\hline right ventricle border / $/ \mathrm{BD} /$ & 110.0 & $\begin{array}{r}153.5 \\
11.2\end{array}$ & $\begin{array}{r}186.0 \\
18.8\end{array}$ & $\begin{array}{r}208.6 \\
11.3\end{array}$ & $\begin{array}{r}241.5 \\
6.5\end{array}$ & & $\begin{array}{r}234.2 \\
15.7\end{array}$ & 7.0 \\
\hline \multicolumn{9}{|l|}{ Breadth: } \\
\hline $\max 2 \operatorname{nal} / C D /$ & 85.0 & $\begin{array}{r}110.0 \\
5.9\end{array}$ & $\begin{aligned} 131.9 \\
11.3\end{aligned}$ & $\begin{array}{r}165.0 \\
9.9\end{array}$ & $\begin{aligned} 169.0 \\
2.0\end{aligned}$ & & $\begin{array}{r}188.1 \\
11.6\end{array}$ & 6.4 \\
\hline minimal /AE/ & 52.0 & $\begin{array}{r}80.5 \\
3.2\end{array}$ & $\begin{array}{r}93.0 \\
8.0\end{array}$ & $\begin{array}{r}117.6 \\
8.3\end{array}$ & $\begin{array}{r}119.0 \\
12.0\end{array}$ & & $\begin{array}{r}139.7 \\
13.8\end{array}$ & 10.5 \\
\hline left ventricle /AF/ & 45.0 & $\begin{array}{r}70.7 \\
5.3\end{array}$ & $\begin{array}{r}84.6 \\
5.6\end{array}$ & $\begin{array}{r}105.0 \\
5.3\end{array}$ & $\begin{array}{r}111.0 \\
6.0\end{array}$ & & $\begin{array}{r}125.7 \\
15.2\end{array}$ & 12.6 \\
\hline right ventricle /AD/ & 75.0 & $\begin{array}{r}92.7 \\
7.0\end{array}$ & $\begin{array}{r}108.6 \\
11.8\end{array}$ & $\begin{array}{r}135.6 \\
9.9\end{array}$ & $\begin{array}{r}135.5 \\
4.5\end{array}$ & & $\begin{array}{r}152.3 \\
12.2\end{array}$ & 8.6 \\
\hline \multicolumn{9}{|l|}{ C1rcunference: } \\
\hline below the coronary groove /ADBCh/ & 228.0 & $\begin{array}{r}322.7 \\
30.5\end{array}$ & $\begin{array}{r}376.7 \\
28.7\end{array}$ & $\begin{array}{r}450.0 \\
22.4\end{array}$ & $\begin{array}{r}476.0 \\
14.0\end{array}$ & & $\begin{array}{r}529.4 \\
41.2\end{array}$ & 8.1 \\
\hline left ventricle / ACE/ & 85.0 & $\begin{array}{r}135.0 \\
4.7\end{array}$ & $\begin{array}{r}164: 2 \\
13: 1\end{array}$ & $\begin{array}{r}186.4 \\
10.6\end{array}$ & $\begin{array}{r}212.5 \\
7.5\end{array}$ & & $\begin{array}{r}221.8 \\
17.2\end{array}$ & 8.0 \\
\hline right ventricle /:DE/ & 143.0 & $\begin{array}{r}187.7 \\
17.4\end{array}$ & $\begin{array}{r}215.9 \\
25.6\end{array}$ & $\begin{array}{r}264.8 \\
20.2\end{array}$ & $\begin{array}{r}263.5 \\
6.5\end{array}$ & & $\begin{array}{r}307.6 \\
27.5\end{array}$ & 9.3 \\
\hline \multirow[t]{2}{*}{ apex /GNLLKG/ } & 94.0 & $\begin{array}{r}136.0 \\
6.0\end{array}$ & $\begin{array}{r}158.7 \\
12.3\end{array}$ & $\begin{array}{r}188.2 \\
21.0\end{array}$ & $\begin{array}{r}190.0 \\
15.0\end{array}$ & & $\begin{array}{r}212.6 \\
21.2\end{array}$ & 10.5 \\
\hline & $n=1$ & $n=4$ & $n=8$ & $n=5$ & $n=2$ & & $n=13$ & \\
\hline
\end{tabular}


earlier, that is, in the age group from $1 / 2$ to 1 year, after which it is markedly lower up to the 5 th year of life.

The average growth rate of the heart is usually slight or totally absent in adult European bison over 5 years old. In males, however, after a short period of cessation ( $5-7$ years of age) further considerable increase in linear measurements of the heart is again observed in the 7-9 year age group. Females do not exhibit so distinct a regression at the age of $5-7$ years, but data for the next age group are unknown.

Table 2

Average percentage increases of linear measurements and mass of the European bison heart.

\begin{tabular}{|c|c|c|c|c|c|c|c|c|c|c|c|}
\hline \multirow{2}{*}{$\begin{array}{l}\text { Measure- } \\
\text { ment }{ }^{1}\end{array}$} & \multicolumn{11}{|c|}{ Ags, yes } \\
\hline & $0-6 / 12$ & $6 / 12-1$ & $1-3$ & $3-5$ & $5-7$ & $7-9$ & $9-11$ & $11-13$ & $1 x-15$ & $15-17$ & $17-23$ \\
\hline & & & & & Male: & & & & & & \\
\hline $\mathrm{bJ}$ & & 29 & ว & 18 & 0 & 5 & 7 & -1 & 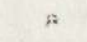 & & \\
\hline BE & & 17 & 30 & 12 & 2 & 13 & -2 & $-\beta$ & $\varepsilon$ & -10 & \\
\hline$A .3$ & & 16 & 21 & if & 11 & $1 ;$ & 20 & -4 & 0.6 & $-?$ & \\
\hline $\mathrm{cy}$ & & 31 & 27 & 24. & -14 & 15 & 4 & 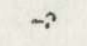 & $-1 \dot{t}$ & & \\
\hline$A B$ & & 27 & 32 & 24 & -9 & $2:$ & -10 & -3 & -3 & & \\
\hline $\operatorname{TRD}$ & 22 & 17 & 33 & 13 & -61.4 & 14 & 0.4 & ן & $?$ & & \\
\hline $\mathrm{BXCC}$ & 24 & 19 & 27 & 13 & 3,5 & 14 & -2 & 4 & 5 & -4 & ? \\
\hline ADECA & 23 & 13 & 27 & 99 & -4 & 17 & -2 & 0.3 & -4 & 3 & \\
\hline $\mathrm{ACE}$ & 23 & 12 & 32 & 23 & -8 & 15 & 4 & -2 & -2 & -4 & \\
\hline$\triangle D B$ & 24 & 14 & 30 & 13 & 1 & 16 & 0.5 & -5 & -6 & 8 & \\
\hline Mass & & 85 & 95 & 47 & -15 & 48 & & 9 & -5 & & \\
\hline
\end{tabular}

\begin{tabular}{lrrrrrrrrr} 
BJ & 43 & 15 & 15 & 9 & 2 & 1 & 4 & -3 & 3 \\
AE & 57 & 17 & 17 & 3 & 4 & 3 & 2 & -9 & -3 \\
$A B$ & 52 & 13 & 18 & 9 & 3 & -1 & -5 & 3 & -1 \\
$C D$ & 29 & 20 & 25 & 2 & 2 & 10 & -2 & -1 & 8 \\
$A E$ & 56 & 15 & 27 & 1 & 11 & 9 & 2 & -12 & 10 \\
PMD & 40 & 21 & 12 & 16 & -1 & 4 & -5 & 4 & 2 \\
PKC & 53 & 16 & 21 & 9 & -1 & 2 & -2 & 14 & -11 \\
ADECA & 42 & 17 & 19 & 6 & 0.2 & 9 & 5 & -9 & 14 \\
ACE & 59 & 21 & 13 & 15 & 0 & 5 & 2 & -10 & 14 \\
ADE & 31 & 15 & 23 & 0.4 & 4 & 7 & 7 & -3 & 15 \\
MaEs & 56 & 41 & 65 & 13 & 9 & 21 & 2 & -9 & 2 \\
\hline
\end{tabular}

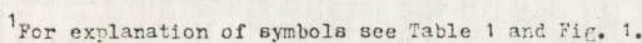

Relative dimensions of the heart, that is, indices, in both sexes differ only slightly in mean values (Table 3 ), and these differences are not significant with $p \leqslant 0.05$. Thus the bison's heart in our study material 


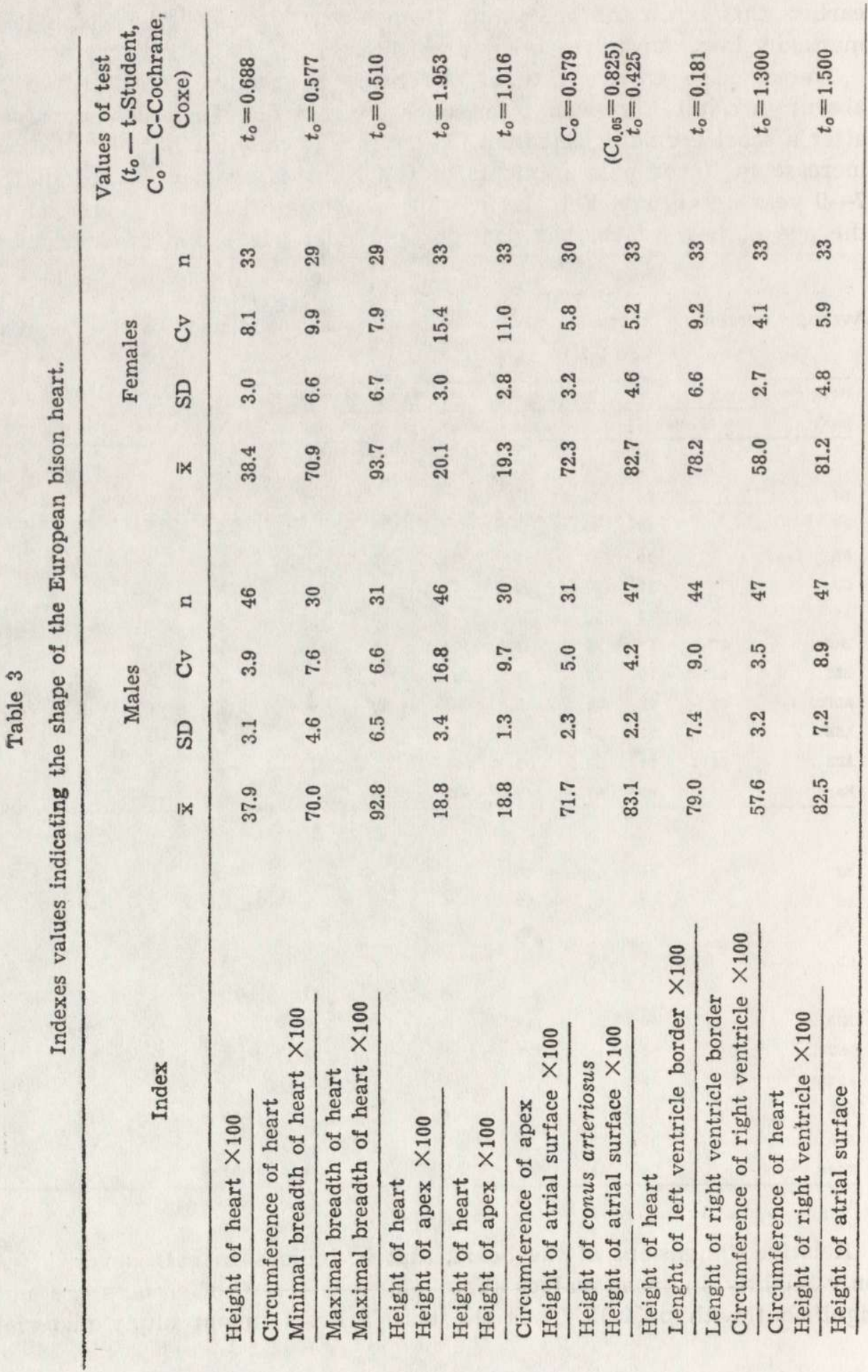




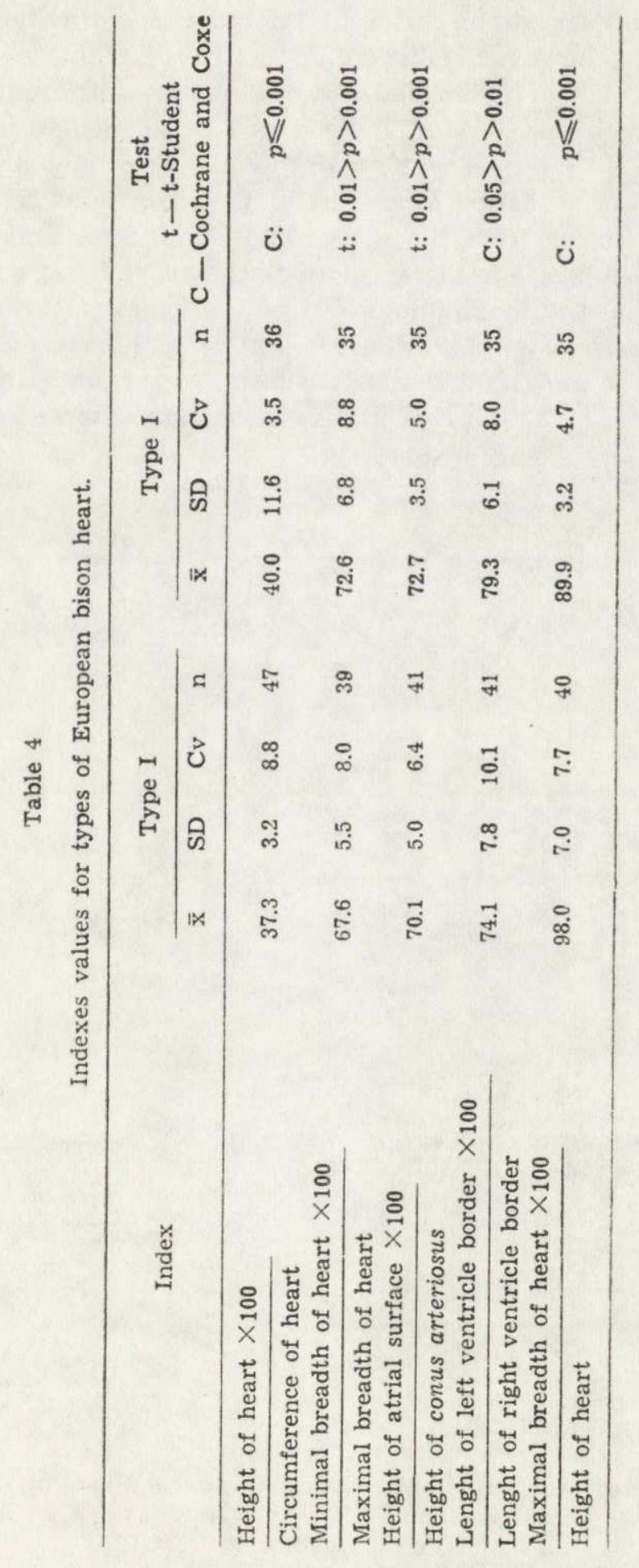


did not exhibit sex dimorphism in its external formation or shape. Certain indices, however, take on distinctly different mean values in the two types of heart described and can serve to differentiate between them. The indices set out in Table 4 are of particular usefulness for this purpose. With the exception of the last one they are far lower for type I heart (widened at the base) than for type II (narrowed at the base). It is clear from the values of these indices that type I heart (in relation to type II) is lower, more flattened and has a higher conus arteriosus, while the maximum width of the heart of the median plane is almost as great as its height (last index).

The weight of the European bison's heart expressed in mean absolute values increases in both sexes in all the groups observed (Table 5). Its
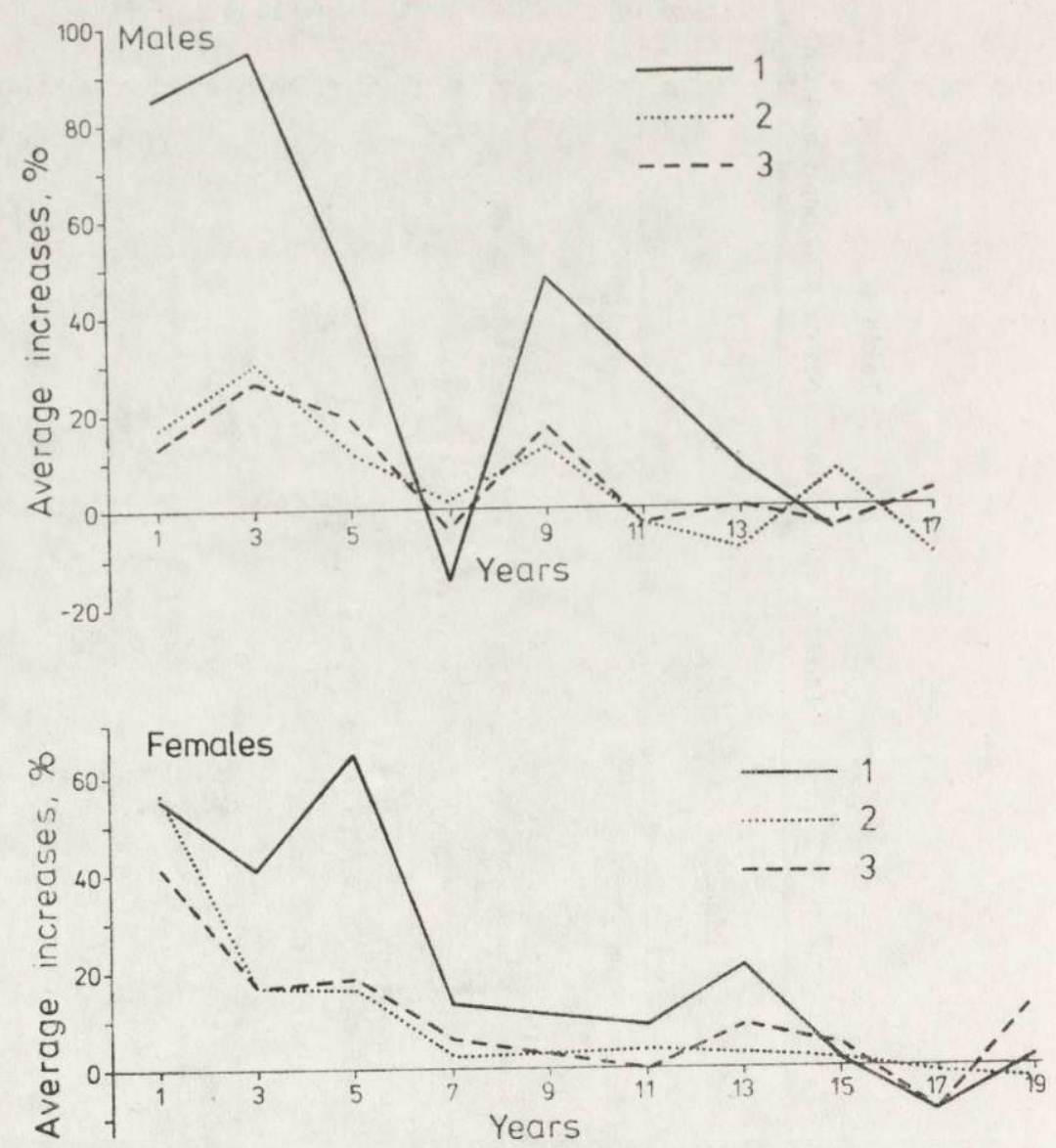

Fig. 2. Growth rate of basic linear measurements and weight of the heart in male and female European bison. 1 - absolute weight; 2 - height of heart; 3 - circumference of heart. 
$1 / 2$ to 3 years of life, and slows down markedly in 3-5 year age group. In adult males there is no distinct increase at all in the weight of the heart without the group 7-9 years old, in which it is observed to increase considerably (Table 2). In females growth rate of the heart in the groups observed is lower (Fig. 2) and more even during the whole period up to 5 years of age. After this only slight increases occur in all age groups: greater in females $11-13$ year old (Table 2), although there are no data available for females from 7-9 years old.

The absolute weight of the European bison's heart exhibits a high correlation with its basic dimensions, for instance, between height of the heart and its weight the coefficient of correlation has the following value: $r=0.805$ for males $\left(t_{o}=7.310\right.$ for $\left.n=31\right)$ and $r=0.976$ for females $\left(t_{o}=22.610\right.$ for $\left.n=28\right)$, with $\left.p \leqslant 0.001\right)$. Similarly the circumference of the heart is highly dependent on its weight, and coefficients of correlation are here respectively: $r=0.802,\left(t_{0}=6.980\right.$ for $\left.n=29\right)$ and $r=0.901$, $\left(t_{o}=10.610\right.$ for $\left.n=28\right)$, with $p \leqslant 0.001$. In both cases they are high and clearly greater in females.

The relative weight of the heart, on the contrary, distinctly decreases with age. During the first months of life it reaches on an average $0.743-0.829 \%$, and in adults about $0.500 \%$ of body weight. In older inmaximum growth rate (Fig. 2) occurs in males during the period from

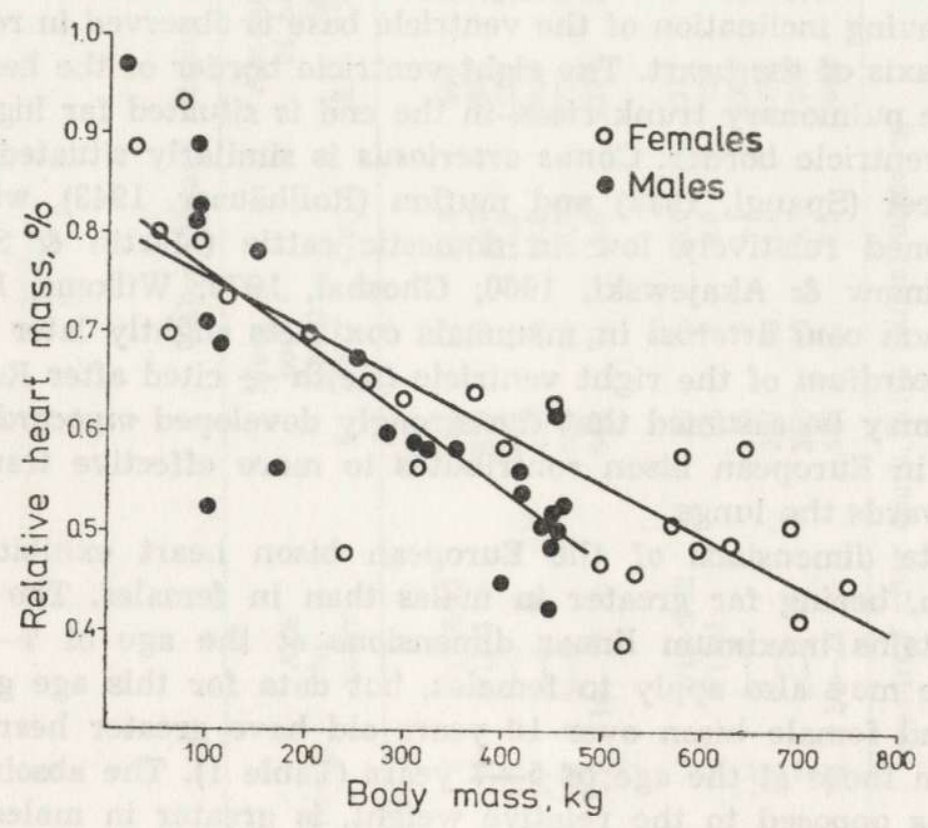

Fig. 3. Correlation of absolute weight of the heart and body weight of the European bison. 
dividuals it increases only slightly, but more clearly in females (Table 5). The relative weight of the heart is distinctly correlated with the animal's body weight (Fig. 3), being for males $r=-0.841 \quad\left(t_{0}=7.450\right.$ for $n=25)$ and for females $r=-0.805\left(t_{o}=6.370\right.$ for $\left.n=24\right)$, both values being statistically significant with $p \leqslant 0.001$.

\section{DISCUSSION}

Two morphological types of heart can be distinguished in European bison. The first of these has a broadened base, with relatively small height and great lateral flattening, and is similar to the heart of $a$ buffalo (Zedenov, 1961). A similar type of heart occurs, although rarely $(23 \%)$ in some species of sheep (Plemjannikov, 1954a, 1954c) and is also characteristic of the horse (Wilkens, 1976). Type II hearts, which in the European bison have an elongated shape and narrow conus, are less flattened laterally and are similar to the heart in domestic cattle (Ackerknecht, 1943; Klimow \& Akajewski, 1960; Zedenov, 1961; Ghoshal, 1975).

In the European bison's heart, especially in type I, conus arteriosus is situated high up and its mean height increases fairly markedly also in adult animals (Table 1). Consequently with increasing age a gradual but continuing inclination of the ventricle base is observed in relation to the long axis of the heart. The right ventricle border of the heart, from which the pulmonary trunk rises, in the end is situated far higher than the left ventricle border. Conus arteriosus is similarly situated high up in red deer (Spangl, 1932) and muflon (Rollhäuser, 1943), whereas it is positioned relatively low in domestic cattle (Martin \& Schauder, 1938; Klimow \& Akajewski, 1960; Ghoshal, 1975; Wilkens, 1976). As myocardium coni arterosi in mammals contracts slightly later than the true myocardium of the right ventricle (Keith - cited after Rollhäuser, 1943), it may be assumed that the strongly developed myocardium coni arteriosi in European bison contributes to more effective transport of blood towards the lungs.

Absolute dimensions of the European bison heart exhibit sex dimorphism, beeing far greater in males than in females. The heart in males attains maximum linear dimensions at the age of $7-9$ years. The same may also apply to females, but data for this age group are scanty and female bison over 10 years old have greater heart dimensions than those at the age of $5-7$ years (Table 1). The absolute heart weight, as opposed to the relative weight, is greater in males than in females (Table 5). In addition the absolute weight of the heart in European bison exhibits a high degree of correlation with its basic linear 


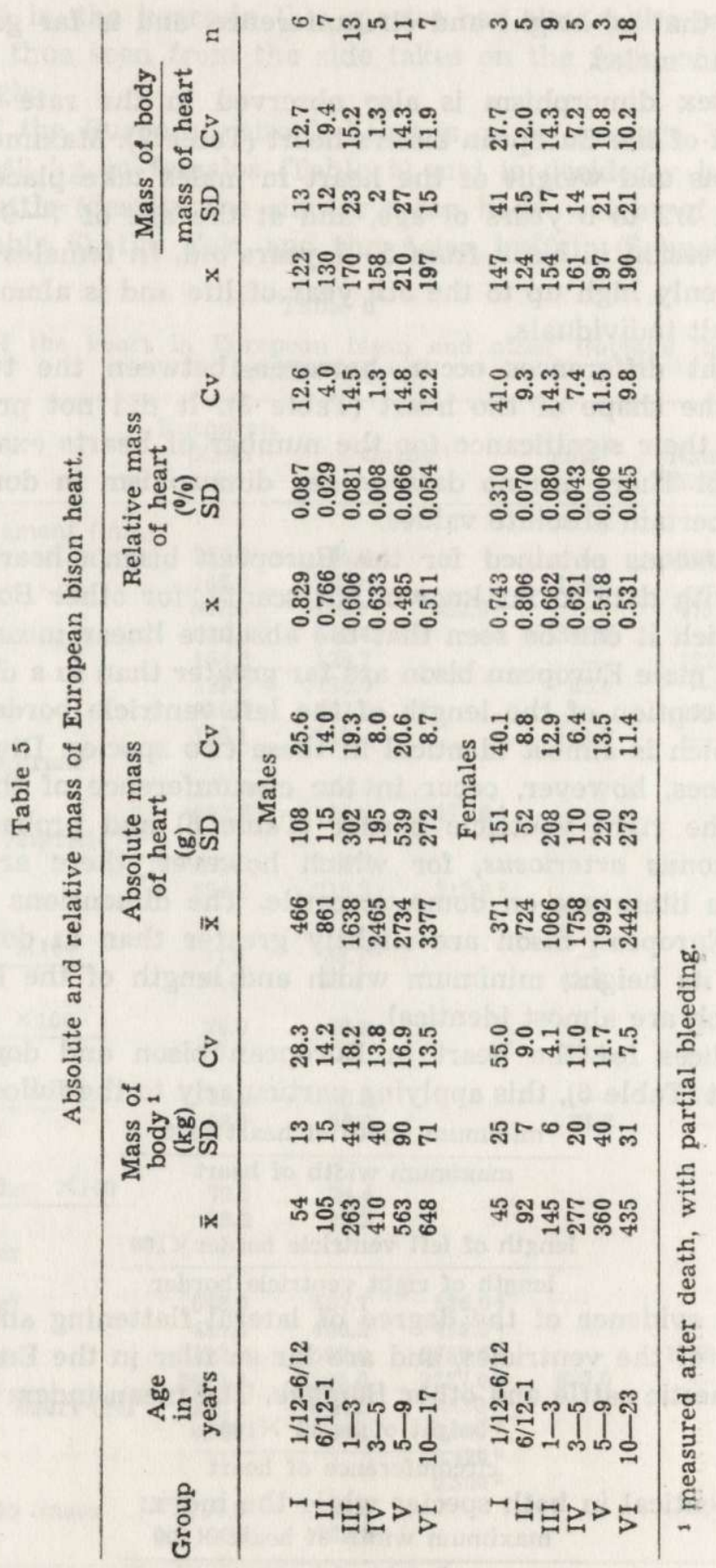


dimensions, that is, height and circumference, and is far greater in females than in males.

Distinct sex dimorphism is also observed in the rate of postnatal development of the European bison's heart (Table 2). Maximum increases in dimensions and weight of the heart in males take place during the period from $1 / 2$ to 3 years of age, and at the age of 7-9 years, with distinct regression in bison from 5-7 years old. In females growth rate is almost evenly high up to the 5th year of life and is almost uniformly small in adult individuals.

Only slight differences occur, however, between the two sexes in respect of the shape of the heart (Table 3 ). It did not prove possible to establish their significance for the number of hearts examined, even with $p \leqslant 0.05$. There are no data on sex dimorphism in domestic cattle apart from certain absolute values.

The dimensions obtained for the European bison's heart have been compared with data so far known, but scanty, for other Bovinae (Table 6), from which it can be seen that the absolute linear measurements of the heart in male European bison are far greater than in a domestic bull, with the exception of the length of the left ventricle border, the mean value of which is almost identical in these two species. Distinctly greater differences, however, occur in the circumference of the heart and length of the right ventricle border (Table 6) and probably also the height of conus arteriosus, for which however, there are no numerical data in literature on domestic cattle. The dimensions of the heart in female European bison are slightly greater than in domestic cows, apart from its height, minimum width and length of the left ventricle border, which are almost identical.

Mean indices for the heart in European bison and domestic cattle are different (Table 6), this applying particularly to the following indices.

$$
\frac{\text { minimum width of heart } \times 100}{\text { maximum width of heart }}
$$

and

$$
\frac{\text { length of left ventricle border } \times 100}{\text { length of right ventricle border }}
$$

which form evidence of the degree of lateral flattening and inclination of the basis of the ventricles, and are far smaller in the European bison than in domestic cattle and other Bovinae. The mean index:

$$
\text { height of heart } \times 100
$$

is almost identical in both species while the index:

maximum width of heart $\times 100$

$$
\text { height of heart }
$$

thas a decidedly greater value in the European bison $(90-98$, average 
about 93), that is, the heart in this species has almost the same width as height and thus seen from the side takes on the form of an almost isosceles triangle.

The mass of the European bison's heart is on an average $3.377 \mathrm{~kg}$ in males and $2.442 \mathrm{~kg}$ in females (Table 5) and is decidedly larger than in domestic cattle (despite the similar mean body weight of these two species - (Table 6), the Yak, and the Asian buffalo (Schneider, 1904;

Table 6

Measurements of the heart in European bison and other Bovinae (males above, females below).

\begin{tabular}{|c|c|c|c|c|c|c|}
\hline Measurement & $\begin{array}{l}\text { European } \\
\text { bison } \\
\overline{\mathrm{x}}\end{array}$ & \multicolumn{2}{|c|}{$\underset{\bar{x}}{\text { Cattle }^{1}}$} & Yak 6 & $\begin{array}{c}\text { Asian } \\
\text { Buffalo }^{6}\end{array}$ & $\begin{array}{l}\text { Steppe } \\
\text { cattle }\end{array}$ \\
\hline \multicolumn{7}{|l|}{ Linear measurement $(\mathrm{mm})$ : } \\
\hline Height of heart & 226.7 & $\begin{array}{l}185.0 \\
193.3\end{array}$ & & $12 \overline{80}$ & 198.0 & $\overline{1740}$ \\
\hline Circumference & 587.6 & 499.6 & $482.0^{4}$ & - & 475.0 & - \\
\hline Minimal breadth & $\begin{array}{l}529.4 \\
154.3\end{array}$ & $\begin{array}{l}501.4 \\
128.7\end{array}$ & & 302.0 & $\overrightarrow{122.0}$ & 476.0 \\
\hline & 139.7 & 130.0 & & 86.0 & - & 126.0 \\
\hline Maximal breadth & 210.7 & 162.5 & & - & 152.0 & - \\
\hline \multicolumn{7}{|l|}{$\begin{array}{l}\text { Length of left ventricle } \\
\text { border }\end{array}$} \\
\hline & $\begin{array}{l}207.0 \\
182.8\end{array}$ & $\begin{array}{l}204.0 \\
184.5\end{array}$ & $177.0^{4}$ & & & \\
\hline \multicolumn{7}{|l|}{$\begin{array}{l}\text { Length of right ventricle } \\
\text { border }\end{array}$} \\
\hline \multicolumn{6}{|l|}{ Indexes $(\%)$ : } & \\
\hline Height of heart $\times 100$ & 37.9 & 38.7 & & - & 41.6 & - \\
\hline Circumference & 38.4 & 38.4 & & 42.4 & - & 36.6 \\
\hline Minimal breadth $\times 100$ & 70.0 & 80.2 & & - & 80.3 & - \\
\hline Maximal breadth & 70.9 & 82.1 & & 93.4 & - & 80.2 \\
\hline Maximal breadth $\times 100$ & 92.8 & 88.4 & & - & 76.8 & - \\
\hline & 93.7 & 86.2 & & 71.8 & - & 90.2 \\
\hline $\begin{array}{l}\text { Length of left } \\
\text { ventricle border } \times 100\end{array}$ & 79.0 & 94.4 & & & & \\
\hline \multicolumn{7}{|l|}{$\begin{array}{l}\text { Length of right } \\
\text { ventricle border } \\
\text { Mass: }\end{array}$} \\
\hline Mass of body (kg) & $\begin{array}{l}648.0 \\
435.0\end{array}$ & $\begin{array}{l}637.1 \\
480.2\end{array}$ & $\begin{array}{l}636.0^{2} \\
439.0^{2}\end{array}$ & & & \\
\hline Mass of heart (g) & $\begin{array}{l}3377.0 \\
2442.0\end{array}$ & $\begin{array}{l}2592.0 \\
22050\end{array}$ & $\begin{array}{l}2750.0^{2} \\
22370^{2}\end{array}$ & - & 1770.0 & 1745.0 \\
\hline Relative mass of heart $(\%)$ & $\begin{array}{r}2442.0 \\
0.511 \\
0.531\end{array}$ & $\begin{array}{r}2205.0 \\
0.442 \\
0.492\end{array}$ & $\begin{array}{r}2237.0^{2} \\
0.430^{8} \\
0.500^{5} \\
0.420^{3} \\
0.500^{3}\end{array}$ & 635.0 & - & - \\
\hline $\begin{array}{l}\text { Mass of heart to mass } \\
\text { of body }\end{array}$ & $\begin{array}{l}197.0 \\
190.0\end{array}$ & $\begin{array}{l}226.0 \\
203.0\end{array}$ & & & & \\
\hline
\end{tabular}


Schubert, 1909; Albrecht, 1957; Koch, 1970; Ghoshal, 1975; Wilkens, 1976). It is interesting to note that it increases in the European bison after reaching maturity also (after the 5th year of life), increasing on an average by about $23 \%$ in both sexes (23.5\% in males, $22.3 \%$ in females).

The relative weight of the heart in adult bison is greater in females $(0.531 \%)$ than in males $(0.511 \%)$, which is certainly connected with successive numerous pregnancies, since as stated by Krasiński and Raczyński (1967), one adult female European bison produces an average of 9 calves for about 10 years. Far higher relative values are reached by the weight of the heart in this species than in domestic cattle (Table 6). It is interesting that the heart in sheep, on the contrary, has greater relative weight in males (Angst, 1928). The increase in relative heart weight in the European bison in relation to domestic cattle is undoubtedly connected with the former's way of life, since in other wild animals such as roe deer, red deer, wild boar or hares (Hesse, 1921; Waldmeir, 1928; Bischofberger, 1928; Gshwend, 1931; Spangl, 1932; Rensch, 1948) it is high or exceeds the values given for the corresponding species of domestic animals.

\section{REFERENCES}

1. Ackerknecht E., 1943: Das Herz. [In: "Handbuch der vergleichenden Anatomie der Haustiere", 2nd ed. Eds. Ellenberger W. \& Baum H.]. Springer Verl., 1: $610-627$. Berlin.

2. Akajewskij A. J., 1962: Anatomia domasnich zivotnych. Izd. Selchoz. Lit., 1: $366-367$.

3. Albrecht R., 1957: Zur Anatomie des Bovidenherzens. Untersuchungen am Jak, Wisent, Bison, Indischen Büffel, Zebu, Zwergzebu und Steppenrind. Morph. Jb., 98: $575-605$.

4. Angst J., 1928: Das Herz des Hausschafes. (Ovis aries L.) Morph. Jb., 59: 209-212.

5. Bischofberger W., 1928: Das Herz des Hasens (Lepus timidus Schreber). Diss., 1-34. Zürich.

6. Empel W. \& Roskosz T., 1963: Das Skelett der Gliedmassen des Wisents, Bison bonasus (Linnaeus, 1758). Acta theriol., 7: 260-299.

7. Empel W., 1962: Morphologie des Schädels von Bison bonasus (Linnaeus 1758). Acta theriol., 6: 54-110.

8. Ghoshal N. G., 1975: Ruminant heart and arteries. [In: Sisson and Grossman's "The anatomy of the domestic animals". 1 st. ed. R. Getty]. Saunders Company, 1: 960-962. Philadelphia, London, Toronto.

9. Gschwend T., 1931: Das Herz des Wildschweines (Sus scrofa L.) Anat. Anz., 72: 49-89.

10. Hesse R., 1921: Das Herzgewicht der Wirbeltiere. Zool. Jb. (Physiol.), 38: 243-264 .

11. Klimow A. \& Akajewski A., 1960: Anatomia zwierząt domowych. PWRiL, 2: 146-202, Warszawa. 
12. Koch T., 1970: Lehrbuch der Veterinär-anatomie. Veb. G, Fischer verl., 3: 22-36, Jena.

13. Krasiński Z. \& Raczyński J., 1967: The reproduction biology of European bison living in reserves and in freedom. Acta theriol., 12: 407-444.

14. Martin P. \& Schauder W., 1938: Anatomie der Haustiere, 3: 378-426, Schickhardt \& Ebner. Stuttgart.

15. Palmgren A., 1928: Herzgewicht und Weite der Ostia atrioventricularia des Rindes. Anat. Anz., 65: 333-342.

16. Pilarski W., Serwatka S., Swieźyński K. \& Węgrzyn M., 1967: New attempts at fixing anatomical material of large mammals. Acta theriol., 12: 453-458.

17. Plemjannikov A. G., 1954a: Morfologičeskie osobennosti serdca u ovec porody kazachskij archaromerinos. Tr. Inst. Eksp. Biol., 2: 23-37. Alma-Ata.

18. Plemjannikov A. G., 1954b: Morfologičeskie osobiennosti serdca kazachskich serstnych koz $\mathrm{v}$ sravnenii $\mathrm{s}$ ischodnymi formami. Tr. Inst. Eksp. Biol., 2: 193-206. Alma-Ata.

19. Plemjannikov A. G., 1954c: Morfologiceskie osobiennosti serdca kazachskich tonko-runnych ovec i ich ischodnych form i novoj porodnoj gruppy priaralskich tonko-runnych. Tr. Inst. Eksp. Biol., 2: 94-112, Alma-Ata.

20. Rensch D., 1948: Organproportionen und Körpergrösse Vögeln und Säugetiere. Zool. Jb. (Physiol.), 61: 337-412.

21. Rollhäuser H., 1943: Uber Gestalt und Bedeutung der Herzohren. Gegenb. Morph. Jb., 88: 249-267.

22. Schneider J., 1904: Gewicht von Organen des Rindes. Z. Fleisch- und Milchh., 14: $393-398$.

23. Schubert F., 1909: Beiträge zur Anatomie des Herzens der Haussäugetiere. Diss., 1-90, O. Franke, Dresden.

24. Spangl S., 1932: Adatoka szervas szivenek anatomia jahaz (zur Anatomie des Hirschherzens). Diss., 1-32, Patria. Budapest.

25. Waldmeier E., 1928: Das Rehherz. Morph. Jb., 59: 567-598.

26. Węgrzyn M., 1968: Blood-vascular system of the European Bison. I Morphology of the heart. Acta theriol., 13: 177-218.

27. Wilkens H., 1976: Herz des Rindes. [In: "Lehrbuch der Anatomie der Haustiere", Eds. Nickel R., Schummer A., Seiferle E. 1 Aufl. Verl. P. Parey, 3: 58-62, Berlin, Hamburg.

28. Zabiński J. (Ed.), 1947-65: Pedigree book of the European Bison. PWN Polish Sci. Publ.: 1-317. Warszawa.

29. Żabiński J. \& Raczyński J., (Eds.), 1965-74: European bison pedigree book. PWN - Polish Sci. Publ.: 1-285. Warszawa.

30. Žedenov W. N., 1961: Legkie i serdce životnych i čeloveka. Diss., 215-426, Gos. Izd. Moskva.

Accepted, August 28, 1985. 